\title{
Cultural Images as an Issue in the Process of Translation
}

\author{
Dagmar Maria ANOCA \\ Department of Russian and Slavic Languages \\ University of Bucharest \\ anocadm@gmail.com
}

\begin{abstract}
In this paper we present some issues that occur during the translation of literary works, especially from Slovak, but also from Slavic cultural sphere, into Romanian, as a result of differences regarding cultural images or linguistic issues. This will be followed by a more thorough systematization in the future. On the basis of Miko's theory of style, we have analysed texts by Slovak writers such as Samo Chalupka, Ivan Štrpka and others, as translated into Romanian by professor Barborică and Ondrej Štefanko. We have highlighted the fact that in some cases the cultural images are within cultural tradition due to the grammatical gender of the word-the main groundwork for an image, analysing the instances in which they cause issues in translation, requiring the translator to resort to different solutions, including displacing the meaning either towards the iconic, or towards the operative, or finding an adequate substitution. Similar situations also occur in the case of a confrontation between two languages, two codes-the linguistic and the artistic, which involve a knowledgeable recipient, trained in the field of art and languages. The issue is also of interest in the context of comparatism.
\end{abstract}

Keywords: Slovak literature, Romanian literature, translation

We define the "cultural image" as a concept with a broad meaning, consisting of a heterogeneous set of elements made up of representations, psychological content, and figurative expressions, which are made up of entities that can be psychological, lexical, semantic, literary, or of several different kinds simultaneously, from the superior system of signals, or even concrete works of art, not only fictional or virtual, cultural symbols and archetypes, without claiming exhaustivity or definitive, unambiguous results.

The main purpose is to notice, determine and signal certain aspects which relate to the tension arising from the confrontation of cultural images (encompassed in the respective cultural codes) in the process of translation, but also of perception, as the first instance in becoming aware of the phenomenon, possibly even to resolve some tension, contradictions, etc. 
An adjacent finality is mentioning certain realities from Slovak culture, names of Slovak authors and their works, as well as some traits of Slovak literature and culture, and the attempt to make them known and to introduce them into a wider circuit.

The idea of this confrontation has emerged after analysing Romanian translations from the works of Slovak poets, as well as from situations which required equalisation of elements from oral creation.

Thus, Slovak folk songs, lyrical as well as ballads, depict, with positive connotations, the images of certain birds, namely kačička (in Romanian rățuşcă 'duckling'), húska (in Romanian gâsculiță 'gosling'), holub (in Romanian porumbel 'pigeon'), holúbok (in Romanian porumbel 'pigeon'-diminutive), holubička (in Romanian porumbiță 'dove'), as metaphor, symbol or allegory. While the metaphor (personification) of the pigeon or dove corresponds to the image of a lover in Slovak as well as in Romanian, which permits their own equivalence, a transposition without gain or loss of stylistic values, the other images prove impossible to render through lexical equivalence. Kačička 'the duckling' is assimilated, for Slovaks, through cultural tradition, with a female character, surrounded by its children-a caring mother (the diminutive tends toward this image), as seen in the eponymous ballad, qualities lacked by the Romanian lexical equivalent which holds, on the contrary, negative, even pejorative connotations. The same is in the case of the representation behind the word húska 'gosling' a poetic, innocent image of nubile womanhood, whereas the Romanian equivalent (gâsculița 'gosling') conveys the image of a woman rather limited intellectually or of questionable morals. Situations like this require skill to find the right solution (depending on the context, the codes of the target culture). Similarly, from the opposite perspective-from Romanian culture to Slovak culture, e.g. the phrase foaie verde... 'green leaf', a frequent repetition in Romanian folklore, while not as "provocative" as the image of girls evoked by the bird names, is, nonetheless, an issue.

Given the relatively limited inventory of representations inspired by nature within folklore, standard solutions can be found (the means of expression in folklore being themselves standardized), by employing a different equivalent image of the same stylistic value.

The following example also comes from folklore. The folk ballad Katarína is about a beautiful Catherine, whose (Slovak) father promised her to the Turks in order to redeem his own life. On the way to the Turkish groom's house, the girl asks the suite to stop by the bank of the Danube. The moment her wish is granted, she jumps into the river. The young Turk then asks the fishermen to raise the net, but only the third time do they manage to tardily remove from the water rybu srdcu lúbu, in Romanian peştele drag inimii 'the fish dear to the heart' of the groom, who is now left alone. The image of the beautiful young bride, reproduced with the 
use of figurative expression, ultimately a metaphorical image, is possible because the Slovak word for fish, ryba, is of feminine grammatical gender, permitting the representations of the two entities to overlap without disturbing connotations.

During the Romantic period, the motif (the image) migrates, as expected, from the field of folklore into the sphere of written literature. Thus Samo Chalupka (1812-1883), in a poem dedicated to the struggle for freedom (Branko), talking about the fate of the nation, evokes the image of a "golden age" for Slovaks, albeit only fragmentary, defining it as a time of freedom: Bolo dobre, ale dávno, / žil na svete Slovák slávno. / Hej, žil si on na slobode, ako ryba v tichej vode. In Romanian Fost-a bine, odinioară / slovacul ducea viață glorioasă. / El trăia în libertate, precum peştele în apă lină. 'It was good, but long ago, / the Slovak lived a life of glory. / He lived in freedom, like a fish in quiet water.' It follows that the image the Slovaks have constructed about themselves is consistent with the representation sustained by the "fish" motif. It is obvious that in translation, say in Romanian, the image may connote other meanings, which, in Slovak culture, are alien to the meaning of the original word's structure.

In the case of the image of the 'fish' as an imagological model of the Slovak and the woman respectively, in the case of a possible translation, the changes in meaning felt by the readers may be due to the richer and more complex polysemy of the word peşte 'fish' in Romanian, as well as due to the inappropriate grammatical gender-the noun denoting the fish in Slovak being feminine and in Romanian masculine. However, if this does not happen, it is also due to certain correspondences and contextual and cultural limitations. In František Miko's (1973) theory of style, this situation may involve, via the translated text—which is a variant of the original text/ prototext-a trait/ particular stylistic valueexotism/ the perception of strangeness as a result of the origin, the differences of linguistic and cultural codes, and even of the temporal factor. The exotism represents a new acquisition for the text, without decisively altering the content, style and form of the work. Usually such "enrichments" of the text are to be expected by the reader, who is aware of the translation being a "different world".

We find a similar situation, without many alternative choices, in the translation of the poem In the River of Heraclitus by Nobel laureate (1996) Wisłava Szymborska. The lexeme peşte/ ryba 'fish' appears in this literary work as well. Being feminine in Polish, the motif caused problems in translating it into Romanian, as the need of a correspondence between the grammatical gender and the real one appeared at one point.

The first to notice the problem of gender (among other problems) in the given poem and to analyse the solutions resorted to by the different translators of the Polish poetess, was professor Constantin Geambaşu, himself a translator into Romanian and exegete of Szymborskian poetry. He points out in his commentary that "as a result of a reducible procedure, the translator proceeds with an 
unmediated identification of the author with the fish (ja, ryba... 'I, the fish') which is feminine in Polish, and masculine in Romanian. This led to an unacceptable grammatical agreement in Romanian: eu, peşte singulară, eu peşte deosebită... (italics in the original) 'I, singular fish, I, special fish' Geambaşu (2002: 170).

To circumvent this awkwardness, Geambaşu proposes another version: $\hat{I}$ râul lui Heraclit / eu, peşte singuratic, peşte deosebit, / (măcar față de peştele copacului şi peştele pietrei) / pictez arar, pentru-o clipită / în solz de argint, peşti mici, / încât negura ar putea străluci nestingherită? 'In the river of Heraclitus / I, a lonely fish, a special fish, / (at least compared to the fish of the tree and the fish of the stone) / do I rarely paint, for just a moment, / little fishes, into silver scales, / so that darkness could shine unhindered?' Szymborska (2003: 42). ${ }^{1} \mathrm{He}$ retains, however, the feminine gender in the second stanza: În râul lui Heraclit / sunt peşti care iubesc, / ochii tăi - spune - strălucesc ca peştele de pe cer, / cu tine vreau să înot spre aceeaşi mare, / o, tu, cea mai frumoasă dintre peşti. 'In the river of Heraclitus / there are fish that love, / your eyes - say - shine like the fish in the sky, / with you I want to swim into the same sea, / o, thou most beautiful of fish.' Geambaşu (2002:171), subsequently adopting the same solution in collaboration with the poetess Passionaria Stoicescu in what we will call, for now, the definitive version: În râul lui Heraclit, / peştele e-ndrăgostit de peşte, / ochii tăi - spune - ca peştele cerului sclipesc, / Cu tine vreau să înot spre aceeaşi mare, / cu tine, cea mai frumoasă dintre peşti. 'In the river of Heraclitus, / the fish is in love with a fish, / your eyes - say - like the sky fish shine, / With you I want to swim towards the same sea, / with you, most beautiful of fish.' Szymborska (2003: 41)

The "correct" version proposed by Geambaşu is justified by "the discerned message in the structure of the original":

Szymborska structures her poem in four stanzas, where the key word fish (italics in the original) has a valorising semantic value, being presented in four instances: as a member of a community (in the first stanza); in an erotic instance (second stanza); in relation to authority/ power (third stanza); in the role of creator, artist. In other words, there are four fundamental elements of human life to be found in the poem: social life, love, power and art. (Geambaşu 2002: 168)

In this case, however, it is our opinion that the feminine gender must also be discarded in that single instance, where it is used under the influence of the original, contaminating the allegorical plane with the referential one, confusing the speaker's lyricism with the authorial attitude. This is why translators think of the feminine gender from the Polish original as a reference to the author's gender,

1 Translation by Passionaria Stoicescu and Constantin Geambaşu. 
but the suggestion is improperly decoded. In the verse in question, the lexeme's gender is the same as in all the other verses of the Polish original, meaning that it is used as a generic name for the species, it has a formal value, and that it should remain the same in translation-the same gender (masculine), used consistently in every verse, because it is the natural formal gender for the given species in Romanian; there was no need for suggesting the feminine gender, as the allegory of the river of Heraclitus and the fish is sufficiently comprehensible. ${ }^{2}$

The fact that the artistic image aimed for by the authors can be correctly decoded, despite the different images of the fish that result from the linguistic plane of the grammatical category of gender, but also from lexical semantic differences (where the greatest difference between the Slovak, Polish and Romanian languages is the polysemy of the word peşte 'fish' in Romanian, where it generates in a stylistic register the slang meaning of pimp), is due to certain profound, symbolic, archetypal, mythical meanings. According to the dictionary of symbols, the fish is an "archetypal symbol [...] with a distinct sexual underlayer, presenting however obvious signs of ambivalence: it appears as a feminine, matricial, as well as a phallic symbol" (Evseev 2001: 147).

If in the case of the "fish" motif, the gender from the referential plane proves to be not only optional, useless, but downright confusing, another example from Slovak literature suggests and recommends keeping the grammatical gender in accordance with the referential/ real one, in order to avoid an image marked by unwanted expressivity.

In the desire to build a cultural bridge and to perceptibly enhance the dialogue between the two cultures, Ondrej Štefanko (1949-2008), a prominent poet of Slovak expression from Romania, but also in the entire body of Slovak literature everywhere, has repeatedly translated and published fragments from the poetry and other works of Ivan Štrpka (1944), one of the most notable contemporary Slovak poets (from Slovakia). In his volume entitled Rovinsko, juhozápad. Smrt' matky (In Romanian Rovinsko, sud-vest. Moartea mamei 'Rovinsko, South-West. Mother's Death,' 1995),-_inspired, according to Slovak literary history, by oriental systems of civilization, by oriental philosophies and mentalities, refusing to accept the European spirit which allowed society to reach an impasse,- -he pays tribute to his mother's memory. On the other hand, it is precisely the presence of the mother's motif that makes this work an homage to life in general. However, according to the poet Macsovszky in his commentary on the given poem, death is that which compels to meditation on the flow of the river of life (Macsovszky 1996: 27). This river that serves as dwelling place for sadness and joy, and departures, but also for the heroism of temporal existence and resistance to fate, is in fact an

2 We present for comparison the original version of the stanza: "W rzece Heraklita / ryba kocha rybę, /twoje oczy - powiada - lśnią jak ryby w niebie, / chce płynąc razem z tobą do wspólnego morza, / o najpiękniejsza z ławiczy.” Geambaşu (2002: 166) 
allegory for the flow of life, for humanity in its struggle for authentic equilibrium (as was, after all, the allegory of "the river of Heraclitus"). For Ivan Štrpka, the sense of humility, reconciliation with the world, resignation, acceptance of things and phenomena as they are, in the spirit of Indian thought, constitute an attempt to renew European (including Slovak) spirituality in order to find balance in life, spiritual balance in a disoriented world. Given these aspects of the message, it is somewhat natural that the volume should be opened by a poem entitled Rovinsko, juhozápad. Voda zrodenia, in our raw translation: Rovinsko, sud-vest. Apa naşterii 'Rovinsko, south-west. The water of birth,' with a motto taken from a Hindu prayer to the god of water: Ó, matka, dovol' mi, aby som sa v tebe vykúpal. (Hindova modlitba k božstvu vody), in Romanian $O$, mamă, permite-mi, să mă scald în tine. (Rugăciunea unui hindus către zeul apei). 'O, mother, let me bathe in you. (A Hindu's prayer to the god of water)' (Štefanko 1997: 110). Next, the motif develops as if in a musical composition, a fugue: Vnikám do teba, matka, / vnáram sa. Rovinná rieka bez mena / sa ospalo obracia a navracia $v$ pomalých / ohyboch - takmer usína. Štrpka (1995: 15) Pătrund în tine, mamă,/ mă scufund. Râul de câmpie fără nume / se-ntoarce şi revine somnoros în meandre/ negrăbite - aproape adormind. 'I enter you, mother,/ I sink. The nameless lowland river/ sleepily turns and returns / in meanders - almost falls asleep' (Štefanko 1997: 110).

It is obvious that the phrase râul de câmpie 'lowland river' refers to the image of the mother/ maternal principle, continuing the idea of the previous verse (I enter you, mother) like a link in the construction of the river-"mother"-life allegory-which ends, relatively speaking (as it closes a cycle which will remake itself), in death,- -as confirmed by the following verses: Tvoje zomieranie ma rodí d'alej, / pred seba, d'aleko do iskrivých rovín, / v ktorých na všetky strany kvitne / moja vlastná protismrt' 'Your dying births me endlessly,/ before me, in the distant sparkling plains,/ where in all directions blooms/ my own counterdeath.' Štrpka (1995: 16) From this point of view, the aforementioned phrase (the mother symbol-metaphor) would be better fitted by a word in the feminine gender, instead of the word râu 'river', which is neuter (i.e. identical to the masculine in the singular). We propose therefore a compensating solution: Apa râului din câmpie. 'The water of the lowland river' (apa 'water' is feminine in Romanian). The penultimate verse also supports this solution: Cesty spät' niet. Voda je samaCale de-ntoarcere nu există. Apa e singura 'There is no way back. The water is the only one' then ends circularly/ cyclically, intertextually, resuming the motto, this time incorporated into the poem: Ó, matka, dovol' mi, aby / som sa v tebe vykúpal Štrpka (1995)—“O, mamă, lasă-mă să mă scald în tine”. 'O, mother, let me bathe in you'. The feminine matrixes of the mother and death motifs from both cultures overlap due to the feminine grammatical gender in both cases.

Tension appears, as a result of grammatical gender, in the translation of the poem entitled Život in Romanian Viața 'Life' by Ivan Krasko (1876-1958), a modernist 
Slovak poet, tutelary spirit of modern Slovak poetry, as described by professor Corneliu Barborică, translator of the author's full body of poetic work. ${ }^{3}$ The lyrical subject challenges life to a battle, the stakes being 'the beautiful daughter of the dark mountains'. The allegory is easily decipherable; a fierce warrior-the poet—is ready to sacrifice himself for the freedom of the motherland-metaphorically personified as 'a maiden from dark mountains', an image identified by the Slovak reader as the Tatra, long imagined as an ancient mythical cradle for the Slavs and therefore Slovaks. The image, reminiscent of medieval tournaments, evokes, in Slovak, the heroism of knights, their determination to put their manhood to test, an interesting moment in modernist poetry, which is usually slow, rather than warlike. Here we have, however, a moment of manifested national desire for emancipation. In this context, the masculine gender of the noun život 'life' could not be more appropriate. The translation, having no other option, speaks of Life (capitalized like in the original) as of a pagan goddess of war, thus evoking an even older period: Hai, Viață, sus! Şi lasă larma, / pe cal, şi pregăteşte arma! [...] Când ziua va muri în zare / tu vei zăcea în coif şi zale. // Ori tu, ori eu! Unul din doi... / te chem, Viață, la război, / din zori adânci şi până-n seară / pentru frumoasa noastră țară! 'Come, Life, get up! And leave the clamour, / mount your horse, and ready your arm! [...] Before the fall of dusk, / you will lie down in armour. // Either you or I! One of us... / Life, I summon you to war, / from crack of dawn to darkest night / for our glorious land!' (Krasko 2001: 110111). Challenging a masculine gender warrior to a fair fight completely corresponds with the traditional image, while fighting a feminine gender combatant implies, as we have seen, the value of "exotism", or is perceived as temporally marked (Popovič 1977). The movements from one stylistic value to another assume their acceptance, which can also be generally seen as an aspect of alterity in literary communication.

The phenomenon can be parallel with the moment when one perceives a work of visual art which replaces a fictive image (triggered by literary means of expression), in contradiction with their grammatical gender. Codes clash, but because of expectations, of a cultural code/ interrogative language, they do not remain without finality; the receiver opens up to exotisms or alterity due to culture-which is, ultimately, a departure from nature. This is why one of Michelangelo's statues, for example, Il Giorno 'The Day', may be at odds with its grammatical gender in a Romanian's mother tongue (ziua), while it is, on the contrary, within the limits of the ordinary for a Slovak, the word deñ 'day' being masculine in both Italian and Slovak. These facts do not produce intense noise on communication channels, as they are countered by cultural acquisitions from the universal heritage of images accessible by cultured, educated people.

Another good example to illustrate the difficulties of rendering gender and especially an entire ensemble of images and ideas is the short story $V$ pasci (in

3 Ivan Krasko (pen name of Ing. Ján Botto) is known to Romanian comparatists for studying in Braşov and Sibiu and being a translator of Mihai Eminescu. 
Romanian În capcană, 'Entrapped') by Etela Farkašová (1943), published in her volume Káva s Bachom, čaj so Chopinom 'Coffee with Bach, tea with Chopin' (2011). The narrator, relying on the postmodernist technique of unveiling the mechanisms of writing, while trying to create an exceptional work of art, finds herself assisted by a mouse-myš, an animal whose name in Slovak is of feminine gender and which generated a homonym, following the example of the English language, the name for the computer peripheral-the mouse. The animal talks about the fate of its "sisters", imitating the feminist discourse, in relation with the advantages enjoyed by its "brothers", discusses about literature, the need for equality, etc. Translating ${ }^{4}$ the story into a language where the animal has a different gender is a real challenge. We offer, as proof, a fragment of a raw translation: Aia mică, poate pentru a şoca şi mai mult, poate doar pentru a se da mare, pentru că aia mică, îşi dădu seama de-acum, e inteligentă şi, pare-se, nu-i lipseşte nici încrederea în sine, ce mai, instruită, emancipată, cine ştie ce ce fel de căi în regnul ei duc la emanciparea femelelor, micuța scoate un chițcăit cum că am fost nevoite să învățăm în vederea acestei colaborări câteva lucruri despre tehnica de calculator, unele dintre colegele mele chiar au absolvit un curs destul de pretențios, inclusiv eu, adaugă ea cu o umbră de mândrie, nu a fost cine ştie cât de interesant, dar dacă vrem să ne perfecționăm, să ajungem în aceleaşi poziții ca frații noştri... 'The little one, maybe to shock even more, maybe to gloat, because the little one, she already realised, is intelligent and, it seems, doesn't lack self confidence, she's educated, emancipated, who knows what roads lead to emancipation of females in her kingdom, the little one squeaks that we had to learn some things about using the computer in order to achieve this collaboration, some of my colleagues even graduated a pretty sophisticated course, including myself, she added with a touch of pride, it wasn't very interesting, but if we want to improve ourselves, to reach the same positions as our brothers...' (Farkašová 2011).

Some postmodern writers deliberately remove this opposition. For example, the bilingual (Slovak-Hungarian) poet Peter Macsovszky (1966) applies a strategy of "deconstruction" of the masculine vs. feminine opposition, he does not hesitate to undertake a mystifying game with the image of gender by publishing a poetry volume entitled Súmrak cudnosti 'Twilight of chastity' (1996) under the female pseudonym Petra Malúchová (Sedlák 2009: 633-635). Wishing to demonstrate the lack of sincerity and credibility of poetry, of literature, expressing distrust in authenticity, giving up lyricism, subjectivism, abandoning the impressionism of perception, he invented his own writing strategy, adopting the so-called "cool aesthetics", resulting in a species the author calls báseň steril, poem - un steril ‘sterile poem’ (Krčméryová 2008: 52, 56-57; Čúzy 2006: 153). Regarding this

4 A translation into Serbian is being attempted by Slovak writer Samo Boldocký from Vojvodina. We received this information from Slovak poetess Viera Benková from Bački Petrovac, Voivodina, whom we would like to thank. 
term, báseň steril sounds, in Slovak, as a rough barbarism due to the neologism steril, rarely used in the colloquial style, although contemporary literary Slovak exhibits a great openness to neologisms and is tolerant towards those of Latin origin, as Latin had an important role in Slovak culture during the evolution of the literary version of the language, but lately it also accepts anglicisms. In the Romanian cultural context, however, the phrase poem steril does not have such an intense impact and rather suggests emptiness of meaning, a cognitive void.

The tension between prototext and the translated version, a tension that influences representations, artistic images, may rise from the competition between the variants of the language or languages they are written in. A special example is the novel Jadviga's Pillow (1997) by Pál Závada, a Hungarian writer of Slovak descent, who proposes a sophisticated game of confrontation between different linguistic systems/ languages: the novel is written in literary Hungarian, slightly marked on the temporal axis (Maruzsné 2002: 325-330). The main body text is "inlaid" with notes in the Slovak subdialect from Tótkomlós, Hungary, but also, on different levels (the work being compositionally structured like a scientific text, with footnote references), with references to the Slovak literary language, therefore two linguistic systems and a diglossia. The symbolic name Osztatni (in Slovak literary spelling, Ostatný), meaning 'the last' and also 'the least', does not mean a lot for an uninformed reader, a speaker of a different language, in the case of a translation. Only after reading the explanation of a third "voice"-a third narrator (the son of the two previous narrators), does the reader get an idea about the view the first narrator, Osztatni, holds about himself. The image of an image about oneself, held by a character, is a means of characterization, where a character's psychology influences their language, taken over by the narrator and manipulated by the author. It is obvious that a text like this is difficult to transpose into a different, third language, that lacks a direct possibility of the same stylistic value to render the game of languages, other than through the translator's footnotes.

In conclusion, we wish to mention an instance of "zero image" held by grammatical categories of the language, which is due to the pronominal value of the pronominal verb ondiat' (it seems that there is a verb with a similar function in Hungarian). In Slovak, the category of "pronominality" forms a class of elements distributed "vertically" along the system of the parts of speech, thereby also generating a verbal pronoun that concretizes its meaning in context. It is usually used when taboo is in question, when the content of the message is or is wished to be uncertain, or as an expletive. All these instances give translators trouble, as it also happens in the case of phraseologisms (proverbs, idioms, etc.), which rely on certain images whose formal rendering in another language does not match their content (exceptions prove the rule). 


\section{References}

Barborică, Corneliu. 2002. Lirică slovacă de la începuturi până azi. [Slovak Poetry from the Beginning to the Present-Day.] Nădlac: Editura Ivan Krasko.

Č́zy, Ladislav et al. 2006. Panoráma slovenskej literatúry III. [Panorama of Slovak Literature III.] Slovenské pedagogické nakladatelstvo.

Evseev, Ivan. 2001. Dicționar de simboluri şi arhetipuri culturale. [Dictionary of Cultural Symbols and Archetypes.] Timişoara: Editura Amarcord.

Farkašová, Etela. 2011. V pasci. Káva s Bachom, čaj s Chopinom. [Coffee with Bach, tea with Chopin.] Bratislava: Slovenský spisovatel.

Geambaşu, Constantin. 2002. Scriitori polonezi (secolul XX). [20 th Century Polish Writers.] Bucureşti: Paideia.

Kasarda, Martin. 1996. Osamelí bežci. Správy z l’udského vnútra. [Lonely Runners. News from the Human Soul.] Levice: Koloman Kertész Bagala.

Krasko, Ivan. 2001. Nox et solitudo. Nădlac: Editura Ivan Krasko.

Krčméryová, Eleonóra. 2008. Poznámky k prozaickej (de)generácii. Pohlad na slovenskú mladú prózu 90. rokov. [Comment on the (de)generation of prose. View on the 90 years of the Young Slovak Prose.] Bratislava: Stimul.

Macsovszky, Peter. 1996. Pohyb riečnych textov. RAK, 1996 (1)

Maruzsné, Sebo Katalin. 2002. Interkulturálne vzt’ahy v románe Pála Závadu Jadvigin vankúšik. In: Jana Pekarovičová (ed.), Slovenčina ako cudzí jazyk, 325-330. Bratislava: Stimul.

Miko, František. 1973. Od epiky k lyrike. [From Epic to Lyricism.] Bratislava: Tatran.

Popovič, Anton. 1977. Teória umeleckého prekladu. [Theory of Literary Translation.] Bratislava: Tatran.

Štefanko, Ondrej. 1997. Călătorind în țara făgăduinței. [Travelling in the Promised Land.] Nădlac: Editura SCŞIK.

Štrpka, Ivan. 1995. Rovinsko, juhozápad. Smrt’ matky. Levoča: Modrý Peter. 2000. Rovinsko, sud-vestul. Moartea mamei. [Rovinsko, South-West. Mother's Death.] Nădlac: Editura Ivan Krasko.

Sedlák, Imrich et al. 2009. Dejiny slovenskej literatúry. [History of Slovak Literature.] Martin-Bratislava: Matica slovenská-Literárne informačné centrum.

Szymborska, Wisława. 2003. In râul lui Heraclit. [In the River of Heraclitus.] Bucureşti: Paideia. 